\title{
Social Cost with No Political Gain: The "Chinese Virus" Effect
}

\author{
Chengxin $\mathrm{Xu}^{\dagger 1}$ and Yixin $\mathrm{Liu}^{\ddagger 2}$ \\ ${ }^{1}$ Seattle University \\ ${ }^{2}$ Florida State University
}

April 2, 2020

\begin{abstract}
Naming a contagious disease, such as COVID-19, by the geographic locality where the disease originates or starts, for example, Wuhan or China, may stigmatize specific ethnic groups related to that locality, and such stigmatizing behavior will further lead to legitimized discrimination, prejudice, and group conflicts. However, as the construction of social stigma relates closely to group identities, creating xenophobia through stigmatizing out-group members may increase in-group solidarity, which can be taken as a political strategy for the government to avoid the blame from citizens. In this study, we experimentally examine: (1) whether labeling COVID-19 as "Chinese Virus" will result in increased stigmatization and xenophobia against Chinese immigrants; (2) whether the "Chinese Virus" label will reduce people's perceived blameworthiness of the federal government. Our results $(N=1,200)$ show that about $16 \%$ of participants located in the U.S. indicated xenophobia against Chinese immigrants, and perceived blameworthiness of the federal government was polarized as expected. Further, although stigmatization was not significantly triggered by the "Chinese Virus" label in full sample, we do find statistically significant treatment effects in multiple political and demographic subgroups (21.47\% increase in Democrats, $16.73 \%$ in Liberals, and $19.93 \%$ in Whites, no effect in conservatives and Republicans while the stigmatization remains at higher levels than other groups). Meanwhile, our list experiment strategy detected no social desirability bias when measuring xenophobia, suggesting that stigmatizing Chinese immigrants was not suppressed by current social norms. However, increased stigmatization did not lead to the reduce of blameworthiness of the federal government in handling the current pandemic.
\end{abstract}

\section{*This manuscript has not been peer-reviewed.}

\footnotetext{
†Email: cxu1@seattleu.edu

${ }^{\ddagger}$ Corresponding author, Email: yl17g@my.fsu.edu
} 


\section{Introduction}

Timely and accurate information communication led by the government serves an essential role in effective confrontation against large scale public emergencies, for example, the worldwide outbreak of COVID-19. While the public is expected to act rationally based on their perception of the information, a growing amount of evidence in psychology and behavioral science suggests that people can be nudged by multiple elements embedded in the information and act in irrational ways. As suggested by mounting psychological evidence on cognition, judgment, and decision making (Kahan et al., 2012; Van Bavel \& Pereira, 2018), even though accurate information is being publicly updated every minute, people's perception and behaviors are still sensitive to other factors, including political language and actions. Indeed, in the United States, for example, people's risk perception of COVID-19 and associated behavioral intentions were highly divided by their reported partisanship at the early stage of the outbreak (Badger \& Quealy, 2020, March 21). Therefore, the government should consider seriously about ways in which it communicates with the public in regard with the emergency for effective disease control, and more importantly, for the well-being of the whole society.

The communication of epidemic diseases such as COVID-19 should receive particular attention because the deadly feature of such disease might exaggerate the negative effect of psychological nudges in the communication, leading to not only the ineffectiveness of controlling strategies but also substantial damage to the society as a whole in a longer term. Among potential nudges related to communication, inappropriate naming of the newly discovered disease, which associates the disease with specific ethnic and economic groups, is proposed to have a strong priming effect that makes people socially stigmatize these groups. A guideline issued by the World Health Organization (WHO) calls upon scientists, national authorities and the media to follow to minimize unnecessary negative effects on nations, economies, and people (Fukuda et al., 2015). However, it is not empirically clear whether naming the disease by its originating locality will lead to social stigmatization and discrimination against the specific ethnic group.

In this study, we experimentally examine the short-term effect of labeling COVID-19 as the "Chinese Virus". Before being officially named as COVID-19, the disease was firstly referred to as "Wuhan Virus" which has potentially stimulated social stigmatization against people in Wuhan City in China. However, even after the official name, U.S. President Donald Trump publicly referred to COVID-19 as "Chinese Virus", as a political reaction against the Chinese government (Rogers et al., 2020, March 19). Since his political misbehavior, there have been increasing numbers of cases on hatred language and violation against Chinese communities reported in multiple localities in the U.S (Tavernise \& Oppel Jr., 2020, March 24). However, given the fact that Chinese immigrants, like other Asian minority groups, have just recently been involved as a part of discussions of racial bias and stereotype (Greenbaum, 2020, March 24), whether the increasing cases against Chinese immigrant was casually resulted from the "Chinese Virus" label is questionable. 
Theoretically, labeling a disease with its geographic locality may create associations that stigmatize the people from that geographic area. Stigma is defined as "an attribute which is deeply discrediting" and individuals or social groups who are stigmatized are "the bearer of a "mark" that defines him or her as deviant, flawed, limited, spoiled, or undesirable" (Jacoby et al., 2005, p. 171). A consensus in social stigma research is that stigma is a mark that legitimatizes treating the bearer in some ways less humanely than those without the mark (Major \& O'brien, 2005). Since dehumanization is an important predictor of intergroup discrimination, prejudice, and conflicts (Kteily et al., 2016), labeling COVID-19 as the "Chinese Virus" may create both explicit and implicit discrimination against Chinese or even the East Asian community in the U.S., or even globally. As a socially constructed psychological cue, stigma is built firstly on initial perception of tangible or symbolic threat. It is then accentuated through perception and frequent social sharing of information, and finally becomes a part of the society "that creates, condones, and maintains such attitudes and behaviors." (Stangor \& Crandall, 2000, p. 73) Given the intense relationship between U.S. and Chinese government in recent years, as well as the political and cultural misunderstandings of modern China, the effect of "Chinese Virus" may contain both tangible (life-threatening) and symbolic (political and cultural conflicts) threats against the U.S society which may exaggerate social stigmatization against Chinese communities.

On the contrary, labeling COVID-19 as the "Chinese Virus" may bring important political benefits to the Trump administration. Although labeling COVID-19 as the "Chinese Virus" may stigmatize Chinese and East Asian communities, the label may strengthen the "in-group love" among the people who share the same group identity. We propose two potential social identities that will lead to potentially different social effect from the mislabel. First, as the Chinese and East Asian communities are still be considered as "perpetual foreigners" (Kim et al., 2011), the Chinese Virus label may arouse nationalism and patriotism in the U.S. Indeed, this could be one of the intention by Trump as he argued that the "Chinese Virus" label was intentionally adopted by himself as a diplomatic reaction to the accusation from the Chinese government that the COVID-19 was brought to Wuhan, the first city where the virus outbroke, by a group of U.S. military soldiers (Rogers et al., 2020, March 19). In this case, we may expect that the people in the U.S. may all approve such label which increases in-group solidarity and in turn reduces their perceived blameworthiness of the Trump administration in handling the outbreak of COVID-19. However, another possibility is that the "Chinese Virus" effect is politically divided, which only arouses the group identity among Trump supporters or general conservatives, as they weight nationalism and patriotism more important on their moral spectrum (Graham et al., 2009). On the contrary, liberals may identify the "Chinese Virus" label as a political propaganda by Donald Trump so that they may ignore its effect when making judgments on the performance and perceived responsibility of the federal government. Furthermore, the blame from liberals could be increased because the label "Chinese Virus" explicitly offends the moral spectrum of most liberals. Thus, it might be more likely to find politically polarized opinion of the blameworthiness of the Trump administration.

In the current study, we tested four preregistered hypotheses regarding the social cost and political gain of "Chinese Virus": (1) The label "Chinese Virus" will lead to social 
stigmatization against Chinese immigrants in the U.S (H1a); (2) The label "Chinese Virus" justifies stigmatization and therefore will lead to less social desirability bias in answering the question regarding stigmatization (H1b); (3) The label "Chinese Virus" will lead to

less blame against the federal government in handling the pandemic (H2); (4) The effect of "Chinese Virus" is divided based on people's partisanship (H3).

\section{Experiment}

\section{Participants}

A total of 1,247 adult participants in the U.S (53.42\% Female, $\left.M_{\text {age }}=36\right)$ were recruited through Amazon Mechanical Turk (MTurk). 47 participants were eliminated because their surveys are incomplete. The final sample size of the experiment was 1,200.

\section{Measurements}

Stigmatization. Since social stigma usually leads to xenophobia and discrimination, we use people's opinion on Chinese immigrants as a proxy of stigmatization. Thus, we ask people to indicate whether they agree or disagree with the statement "Chinese immigrants damage the public health in the U.S.".

Blameworthiness. Blameworthiness is measured by a survey instrument inviting respondents to indicate the extent to which the federal government is deserving of blame for the outbreak of COVID-19 (the disease name was manipulated as "Chinese Virus" in the treatment group) (James et al., 2016).

\section{Procedure}

The experimental procedure is illustrated in Figure 1. The experiment (preregistration: osf.io/bh258) was delivered in terms of a survey (see Appendix 8). After reading the consent announcement and agreeing to participate, participants were randomly assigned into two groups to read a message about the outbreak of COVID-19 (control group) or Chinese Virus (treatment group). Following the message, participants were asked to indicate to what extent they believe the federal government was blameworthy for the current COVID-19 (control group) / Chinese Virus (treatment group) outbreak on a Likert scale $(0=$ not at all to blame, $100=$ completely to blame). Then participants were further randomly assigned into two subgroups as a part of list experiment technique (Miller, 1984). In detail, in each experimental condition (COVID-19 or Chinese Virus), participants were randomly assigned into the list control group, where they were required to read three statements regarding the message on outbreak they just read, or the list experiment group, where they were required to read three same statements in the list control group and one 
sensitive statement regarding Chinese immigrants ("Chinese immigrants damage the public health in the U.S."). After reading these statements, respondents were asked to indicate how many statements they agreed with. The sensitive statement about Chinese immigrants was presented as a separate opinion question in the list control group. After answering these questions which measure our major outcome variables, data of demographic information (gender, age, race/ethnicity, income, partisanship, political ideology), risk perception regarding COVID-19, and usage of Twitter/Facebook were collected as covariates for the following data analysis. Upon finishing the survey, each participant was award with 0.25 USD. The survey was delivered on March 25, 2020 and was closed on March 26 when the total number of participants met the preregistered sample size.

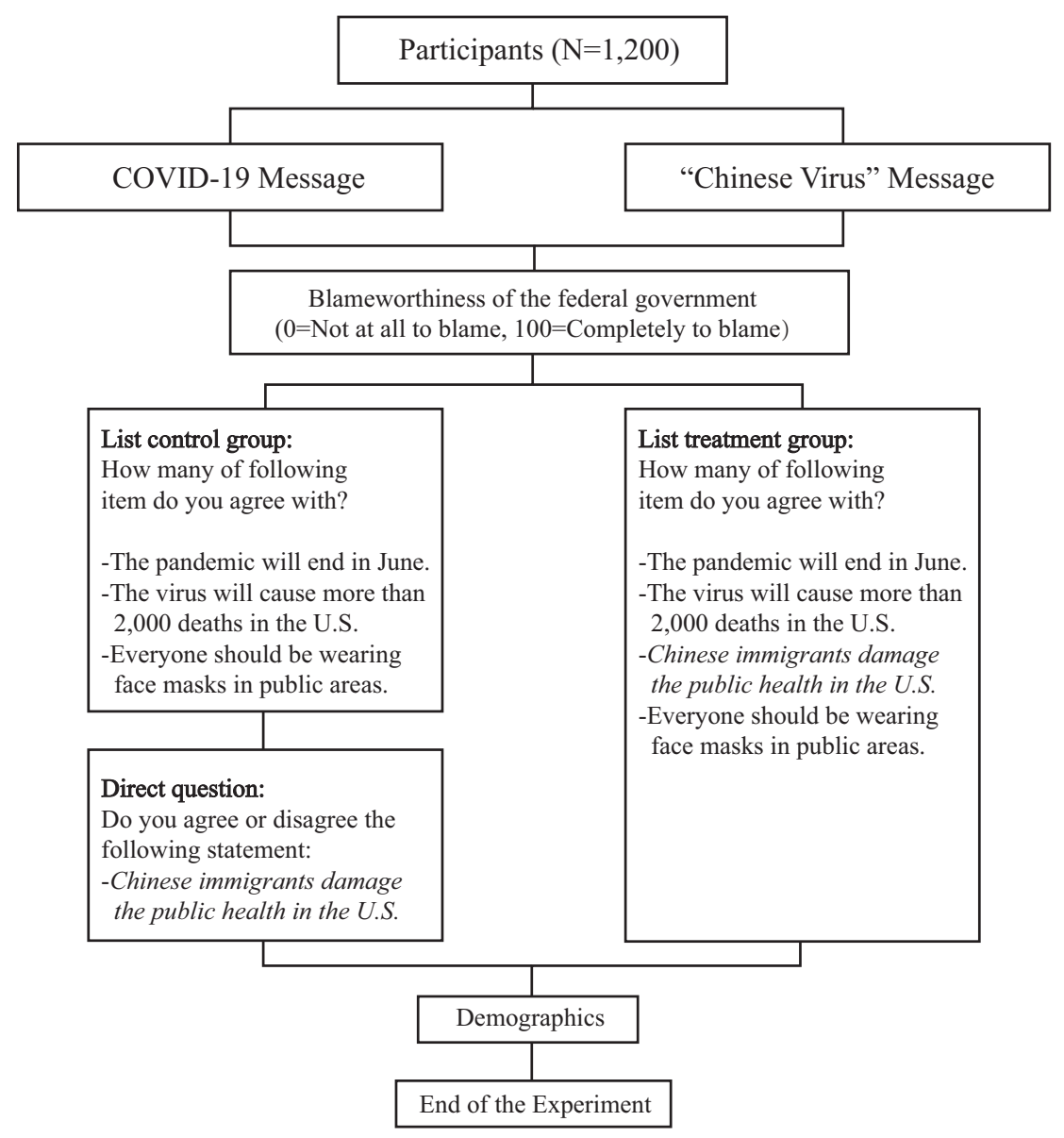

Figure 1: Experimental procedure

The list experiment technique helps us to capture people's opinions regarding Chinese immigrants in the COVID-19 outbreak in the U.S. without suffering from potential social desirability bias. Sensitive questions regarding social stigma and discrimination are usually suffered from social desirability bias so that to elicit truthful answers to these questions are challenging. As a widely used solution to this problem, list experiment provides respondents a greater degree of privacy by asking only the number of agreed statements. Because people are randomly assigned into the list control and treatment group, the proportion of the 
respondents whose answer is affirmative to the sensitive item ("Chinese immigrants damage the public health in the U.S") can be estimated under certain assumptions by simply computing the difference in the mean responses between those two groups (Imai, 2011).

\section{Results}

\section{Descriptive statistics}

Compared to the American general population, our subjects are more liberal and have more Democrats. In summary, $48.92 \%$ respondents are liberal, $23.92 \%$ are conservative, $45.42 \%$ are Democrats and $24.33 \%$ are Republicans. To adjust this "liberal bias", we include weighted results in the additional analysis part. Although our sample is not representative enough, it contains a broad range of social demographic characteristics. Appendix 1 presents the full information of our sample characteristics. Next, we summarize our measurements on the item count, blameworthiness, and proportion of direct stigmatization in the sample.

Table 1: Item count

\begin{tabular}{rrrrrrrrr}
\multicolumn{1}{c}{ COVID-19 } \\
\hline Item & Frequency & Proportion & Frequency & Proportion & Frequency & Proportion & Frequency & Proportion \\
\hline 0 & 14 & $4.71 \%$ & 15 & $4.59 \%$ & 17 & $5.82 \%$ & 11 & $3.59 \%$ \\
1 & 134 & $45.12 \%$ & 126 & $41.31 \%$ & 139 & $47.60 \%$ & 131 & $42.81 \%$ \\
2 & 130 & $43.77 \%$ & 124 & $40.66 \%$ & 115 & $39.38 \%$ & 122 & $39.87 \%$ \\
3 & 19 & $6.39 \%$ & 29 & $9.51 \%$ & 21 & $7.19 \%$ & 31 & $10.13 \%$ \\
4 & & & 11 & $3.61 \%$ & & & 11 & $3.59 \%$ \\
Sample size & 297 & & 305 & & 292 & & 306 & \\
\hline
\end{tabular}

We report the descriptive statistics of item counts in our list experiment in Table 1. First, in both COVID-19 and Chinese Virus list treatment groups (the 4-item group), percentages of reporting extreme item counts ( 1 or 4 ) are less than $9 \%$. In other words, more than $90 \%$ of respondents' opinions of each item cannot be detected by the researchers. Therefore, our list design provided a good protection on respondents' truthful answers (Coffman et al., 2017). Second, our respondents have not concentrated their answers on any one items' choice, so each item is debatable among respondents without ceiling or floor effect (Blair \& Imai, 2012; Glynn, 2013). Moreover, distributions of each choice of items between 3-item and 4-item experimental subgroups are similar, which indicates that the sensitive treatment item had no design effect on respondents' opinions of other items (Blair \& Imai, 2012). Combining all these item count statistics, our list experimental design provided an effective measure.

In general, our respondents have very polarized opinions on the blameworthiness of federal government in the COVID-19 pandemic. Figure 2 shows that people's perceived 
blameworthiness polarizes between 0 to 100 . After breaking down the sample by different social characteristics, Democrats, liberals, and minorities have indicated much higher levels of blameworthiness on the federal government than Republicans and conservatives. In addition, $13 \%$ respondents in the COVID-19 group and 14\% respondents in the Chinese Virus group have directly agreed that Chinese immigrants damage the public health in the U.S. This direct stigmatization has not varied much between different labels (the middle plot in Figure 4).
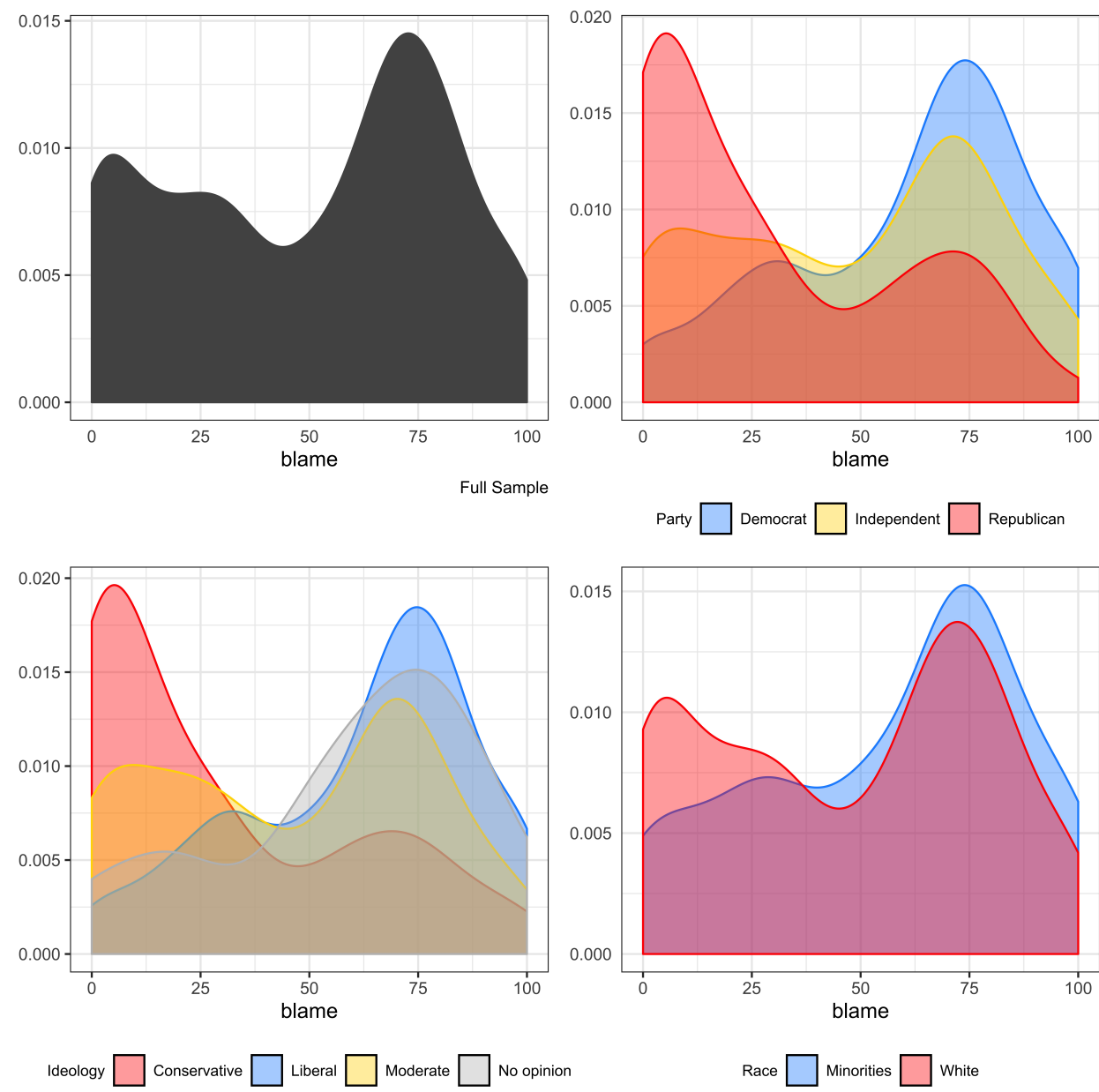

Figure 2: Blameworthiness density distribution: Full sample and subgroups

\section{Main findings}

\section{True stigmatization}

We compare mean differences between list control group (3-item) and list treatment group (4-item) within both the COVID-19 and "Chinese Virus" groups to measure the true stigmatization (Figure 3). Contrary to our hypothesis H1a, social stigmatization was not only detected in the Chinese Virus group, but also in the COVID-19 group. Mean differences 
among 3-item and 4-item subgroups in the COVID-19 is 0.1372 (significant at $p<0.05$ level), which means that $13.72 \%$ of respondents in the COVID-19 group have presented true social stigmatization on Chinese immigrants. On the other side, the proportion of true social stigmatization in the Chinese Virus group is $19.38 \%(p<0.01)$. These facts reveal that the social stigmatization on Chinese immigrants is prevalent in the current COVID-19 pandemic. Mislabeling "Chinese Virus" leaded 5.66\% increasing of the true stigmatization proportion in the sample, but this effect is not statistically significant (the rightmost plot in Figure 4). However, the treatment effect of mislabeling "Chinese Virus" is heterogeneous across different demographic subgroups, so the overall treatment effect could be canceled out. We discuss the heterogeneous treatment effects in the later sections.

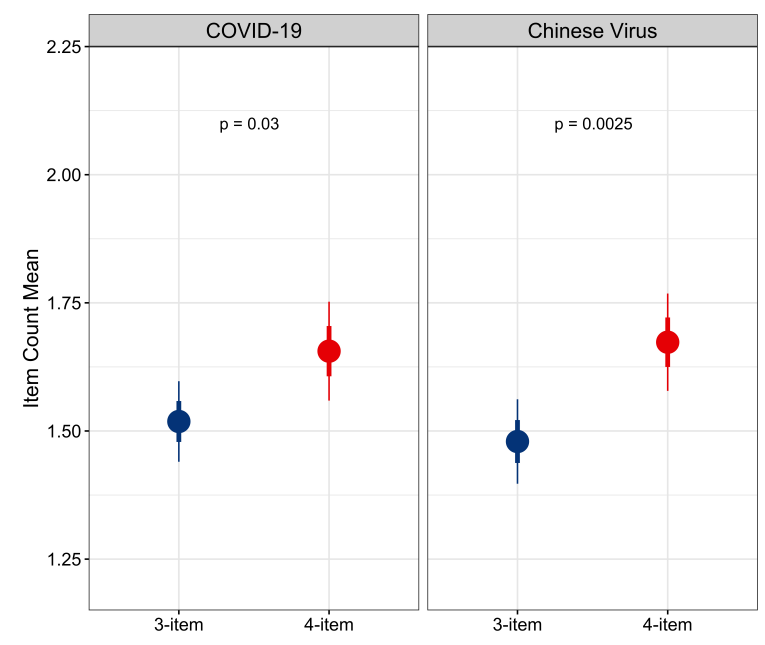

Figure 3: Difference in means: True stigmatization. The vertical bars indicate $95 \%$ confidence intervals.

\section{Social desirability effect}

Next, we compare the proportion of direct and true stigmatization on Chinese immigrants to measure whether the social desirability effect appears. We follow Coffman et al. (2017) to construct the social desirability effect measurement. First, we observed direct question answer as $d_{i}(0,1)$, and 3-item count answer as $c_{i}$ (between 0 to 3). Second, we calculated the sum of both questions as $y_{i}^{D}=d_{i}+c_{i}$. Third, we coded the 4-item count answer with one sensitive statement as $y_{i}^{S}$ (between 0 to 4 ). Ideally, if there is no social desirability effect, $y_{i}^{D}=y_{i}^{S}$. So, the change in sensitive "Agree" can be defined as $\mu=y_{i}^{S}-y_{i}^{D}$. To have a more precise analysis, we put our estimators into a regression with covariates. The model is:

$$
y_{i}=\beta X_{i}+\mu S_{i}, \begin{cases}y_{i}=y_{i}^{D} & \text { when } S_{i}=0 \\ y_{i}=y_{i}^{S} & \text { when } S_{i}=1\end{cases}
$$


Where, $S_{i}(0,1)$ is the item-count list treatment and $X_{i}$ is a matrix of control covariates. We use State fixed effects to control heterogenous pandemic severity by different states, and we also cluster standard errors at the State level. In this setting, $\mu$ is our interested coefficient of the social desirability effect. Table 2 presents the social desirability effects in both COVID-19 and Chinese Virus group, in the full sample and demographic subgroups. We have surprisingly found no support to hypothesis H1b as there is no statistically significant social desirability effect in our sample, except for the minority respondents. Minority respondents have presented implicit stigmatization on Chinese immigrants ( $44 \%$ higher than their direct stigmatization), but this difference has been eliminated when they saw the "Chinese Virus" mislabel. We discuss the treatment effect on each demographic subgroup in the exploratory analysis section. In conclusion, the social stigmatization on Chinese immigrants in the pandemic is expressed explicitly without pressure from established social norms. This evidence is strongly contradicted to other studies of discrimination on social disadvantage groups such as African Americans, Muslins, and homosexual (Aronow et al., 2015; Blair \& Imai, 2012; Coffman et al., 2017; Glynn, 2013).

Table 2: Social desirability

\begin{tabular}{|c|c|c|c|c|c|c|}
\hline & \multicolumn{3}{|c|}{ COVID-19 } & \multicolumn{3}{|c|}{ Chinese Virus } \\
\hline & Direct stigmatization & Social desirability & P-value & Direct stigmatization & Social desirability & P-value \\
\hline \multirow[t]{2}{*}{ Full Sample } & 0.13 & 0.02 & 0.77 & 0.14 & 0.08 & 0.23 \\
\hline & $(0.34)$ & $(0.07)$ & & $(0.35)$ & $(0.07)$ & \\
\hline \multirow[t]{2}{*}{ Democrat } & 0.09 & 0.06 & 0.58 & 0.09 & 0.16 & 0.14 \\
\hline & $(0.29)$ & $(0.10)$ & & $(0.29)$ & $(0.11)$ & \\
\hline \multirow[t]{2}{*}{ Republican } & 0.19 & 0.16 & 0.39 & 0.29 & -0.00 & 1.00 \\
\hline & $(0.39)$ & $(0.18)$ & & $(0.46)$ & $(0.18)$ & \\
\hline \multirow[t]{2}{*}{ Independent } & 0.15 & 0.01 & 0.93 & 0.11 & 0.15 & 0.29 \\
\hline & $(0.36)$ & $(0.11)$ & & $(0.32)$ & $(0.14)$ & \\
\hline \multirow[t]{2}{*}{ Liberal } & 0.08 & -0.06 & 0.55 & 0.09 & 0.16 & 0.10 \\
\hline & $(0.27)$ & $(0.09)$ & & $(0.28)$ & $(0.10)$ & \\
\hline \multirow[t]{2}{*}{ Conservative } & 0.22 & 0.30 & 0.12 & 0.25 & 0.08 & 0.69 \\
\hline & $(0.42)$ & $(0.19)$ & & $(0.44)$ & $(0.19)$ & \\
\hline \multirow[t]{2}{*}{ Moderate } & 0.14 & 0.04 & 0.75 & 0.16 & -0.05 & 0.70 \\
\hline & $(0.35)$ & $(0.14)$ & & $(0.37)$ & $(0.13)$ & \\
\hline \multirow[t]{2}{*}{ White } & 0.13 & -0.05 & 0.50 & 0.15 & 0.09 & 0.25 \\
\hline & $(0.33)$ & $(0.08)$ & & $(0.36)$ & $(0.08)$ & \\
\hline \multirow[t]{2}{*}{ Minorities } & 0.15 & 0.44 & 0.00 & 0.12 & 0.03 & 0.85 \\
\hline & $(0.36)$ & $(0.15)$ & & $(0.32)$ & $(0.17)$ & \\
\hline
\end{tabular}

Notes: Standard errors are in brackets. The social desirability effect is the coefficient $\mu$ on $y_{i}$ with covariates and State fixed effects, and its standard error has been clustered at the State level. Direct stigmatization is the sample mean of the direct question.

\section{Blameworthiness}

We found no supportive evidence for hypothesis H2 regarding blameworthiness. According to the leftmost plot in Figure 4, respondents' opinion on the blameworthiness of the federal government is nested at 50\% for both COVID-19 and Chinese Virus groups. This result holds for not only the full sample analysis, but also for partisanship, ideology, and race subgroups. These null findings provide insights for the current federal government pandemic management by showing that mislabeling COVID-19 as the "Chinese Virus" cannot gain political benefits (reduce blame) for the federal government. 

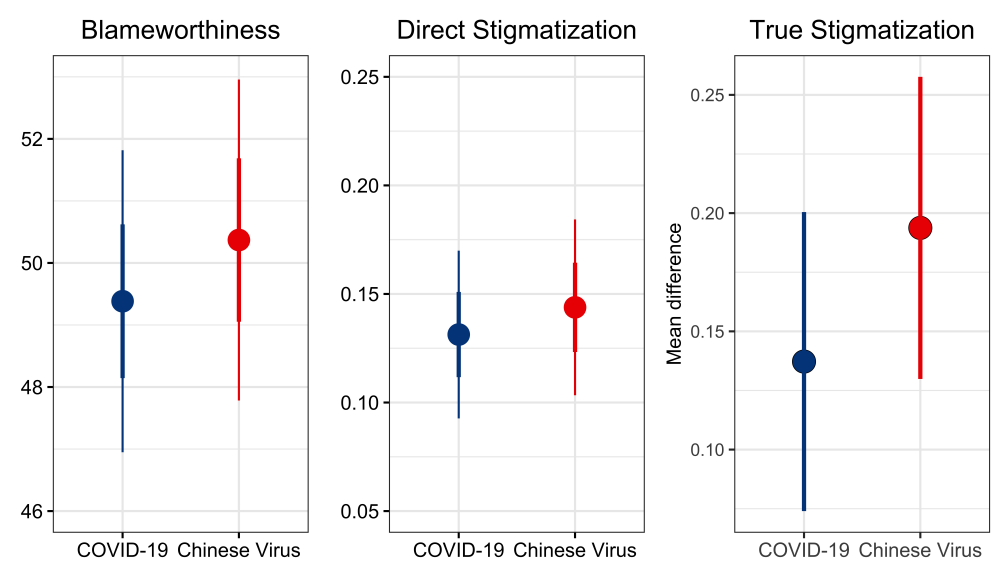

Figure 4: COVID-19 versus Chinese Virus main effects: Blameworthiness, direct stigmatization and true stigmatization. In the blameworthiness and direct stigmatization plots, the vertical bars indicate $95 \%$ confidence intervals. In the true stigmatization plot, the vertical bars indicate standard errors.

\section{Treatment effect by partisanships}

As pre-registered, we break down the true social stigmatization toward Chinese immigrants into partisanship subgroups (Figure 5). Across three partisanship groups, we have not found true stigmatization toward Chinese immigrants among either Republicans or Independents. However, Democrats showed increased social stigmatization toward Chinese immigrants when they saw the "Chinese Virus" label. In the Chinese Virus group, the Democrats' true stigmatization proportion is $21.47 \%(p<0.05)$. This result is unexpected, because the "Chinese Virus" mislabel is publicly used by the President Trump and some other Republican politicians. This may indicate that the "Chinese Virus" label relates more to the citizenship identity that shared within all Americans instead of the political identity. Another possible explanation of our result is that the sample powers among different partisanship groups are different. Democrats in our sample $(N=587)$ outnumber Republicans $(N=292)$ and Independents $(N=363)$. In addition, respondents' partisanship identities may not overlap with their ideology identities. Lean liberal Republicans and lean conservative Democrats may cancel out the treatment effects in opposite ways. To validate this assumption and have a comprehensive understanding of the "Chinese Virus" treatment effect on social stigmatization, we subgroup our sample in ideology and race in the next section. In addition, we run some robustness checks.

\section{Exploratory analysis}

\section{Ideology, race and social stigmatization}

Figure 6 reports the heterogeneous treatment effect across three ideology subgroups. Among liberal respondents, we have not found significant social stigmatization in the COVID19 group. However, $16.73 \%$ of liberals in the Chinese Virus group have reported agreeing on the social stigmatization statement $(p<0.05)$. Therefore, the "Chinese Virus" mislabel have 

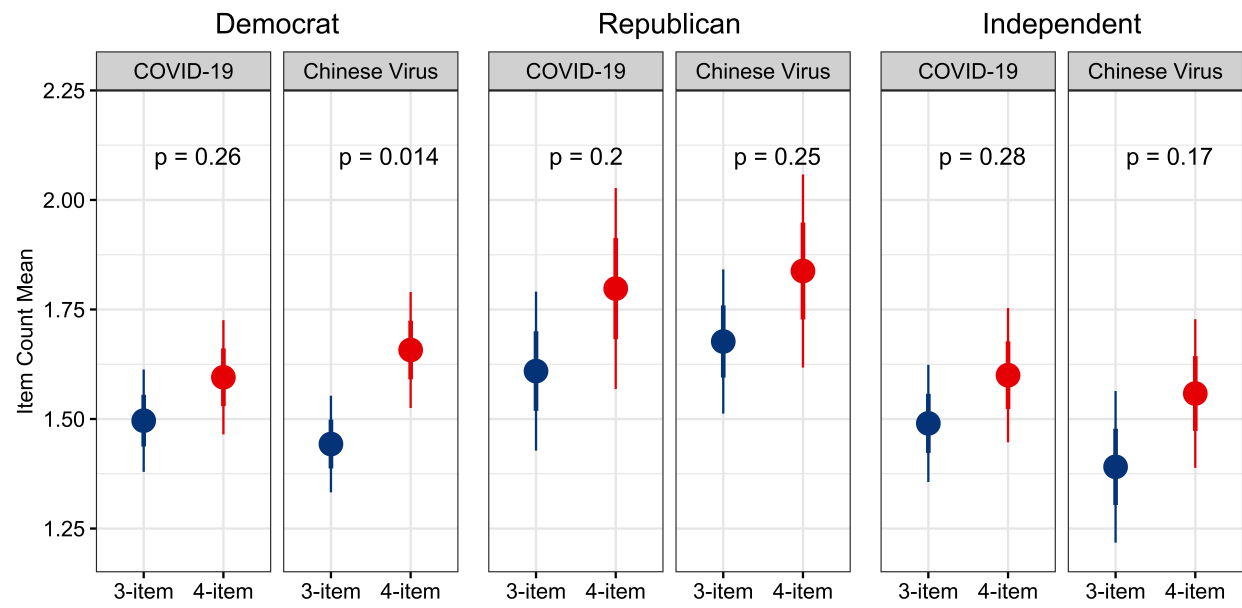

Figure 5: Differences in means: True stigmatization subgroup by party. The vertical bars indicate $95 \%$ confidence intervals.

led $16.73 \%$ of liberals to stigmatize toward Chinese immigrants. Conservatives consistently hold agreement on the social stigmatization statement, 32.41\% $(p<0.05)$ in the COVID-19 group and $27.95 \%(p<0.1)$ in the Chinese Virus group. Moderate respondents have not presented significant bias toward Chinese immigrants in both experimental groups. These results reveal that the conservatives have stronger and more consistently racial bias toward Chinese immigrants than Liberals no matter how the coronavirus is labeled. However, the "Chinese Virus" mislabel maybe effective to some liberals who had no racial bias on Chinese immigrants.
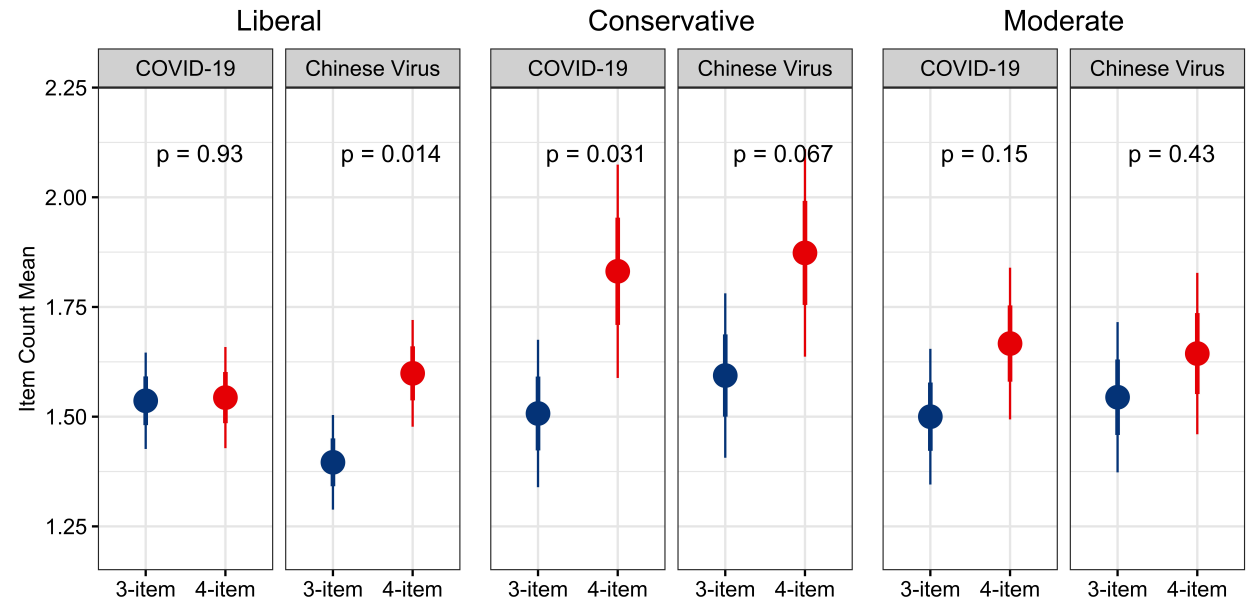

Figure 6: Differences in means: True stigmatization subgroup by ideology. The vertical bars indicate $95 \%$ confidence intervals.

We further report the mean difference of item counts between whites and minorities in Figure 7 The results between whites and non-whites present a contrasting pattern. White respondents in our sample did not report significant bias toward Chinese immigrants in the 
COVID-19 groups, but 19.93\% ( $p<0.01$ ) of white respondents in the Chinese Virus group agreed on the statement of anti-Chinese immigrants. Minority respondents hold very strong bias toward Chinese immigrants in the COVID-19 group $(46.77 \%, p<0.01)$. However, this effect has been eliminated after they saw the Chinese Virus mislabel information. The regression results of the item count measures with covariates have been reported in the Appendix 2.
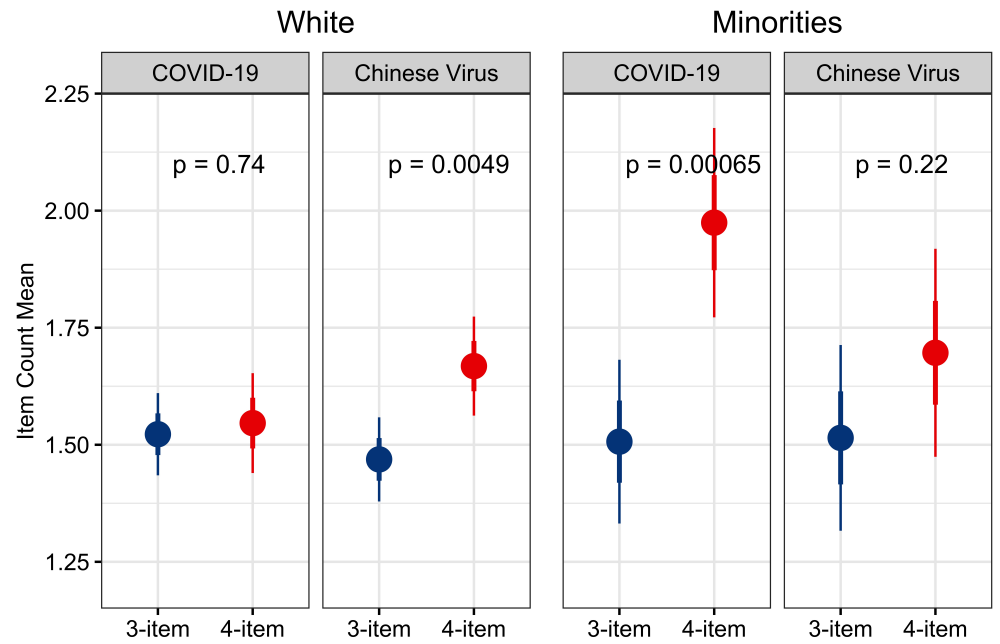

Figure 7: Differences in means: True stigmatization subgroup by race. The vertical bars indicate $95 \%$ confidence intervals.

\section{Robustness analysis}

We run several robustness checks on our findings. First, we employ Blair \& Imai (2012) multivariate maximum likelihood estimation method (MLE) of item count to measure the probability of agreeing on the sensitive item. We construct the covariate with the "Chinese Virus" treatment binary variable to see whether the "Chinese Virus" leaded greater probability to agree on the social stigmatization statement. The complete plot results of each demographic subgroup are reported in the Appendix 3. Similar to the difference-inmeans estimation, the "Chinese Virus" treatment has significantly increased 13.57 proportion $(p<0.05)$ probability of agreeing the social stigmatization statement among liberals and has significantly increased 8.98 proportion $(p<0.1)$ among whites. Minority respondents have received counter effect from the "Chinese Virus" treatment. Their probability of stigmatizing Chinese immigrants has been decreased by 28.71 proportion $(p<0.05)$. Compared to the difference-in-means estimations, we have not found significant "Chinese Virus" treatment effects on Democrats.

Second, we re-weight our sample to match the U.S. population distribution of partisanship and ideology with the iterative proportional fitting (raking) to reduce the "liberal 
bias" (Deville et al., 1993). We refer the Gallup survey of ideology in $2019^{1}$ (37\% conservative, 24\% liberal and 35\% moderate) and party affiliation in $2020^{2}$ (30\% Republicans, $30 \%$ Democrats, and 36\% Independents) to construct the reference population distribution. Overall, the weighted-data and our original data have similar outcomes.

Finally, we exclude respondents who failed to answer the manipulation check question (86 people, 7\%), and run the regression analyses again to diagnose potential treatment noncompliance issue. Based on the $7 \%$ noncompliance rate, we have found similar results between the full sample and the manipulation check passed sample. The comparisons between the original data, weighted-data, and manipulation passed sample regression results are in Appendix 4 and Appendix 5 for each main outcome variable.

\section{Correlational analysis}

In addition to the above evidences from causal inference, our analysis on covariates in predicting the federal government blameworthy and the direct social stigmatization also provide some correlational findings. First, older people, people with higher worried level, people spent more time on Facebook/Twitter, liberals and moderates (compare to conservatives), and Democrats (compare to Republicans and Independents) have blamed more on the federal government in the pandemic management. Second, people with lower income, people spent more time on Facebook/Twitter, and conservatives (compare to liberals) have present stronger direct stigmatization toward Chinese immigrants. The full regression results of blameworthiness and direct stigmatization are in the Appendix 6 and Appendix 7 .

\section{Conclusion}

Naming a newly discovered, contagious, and fatal disease such as COVID-19 by its related geographic localities has long been suggested to have substantial threats to certain ethnic or racial groups of people in both short and long term. Such naming strategy primes people to stigmatize people from that locality and legitimizes discrimination, dehumanization, conflicts, and attacks. In addition, the naming effect could be enhanced when it is abused by the government leader strategically for political purposes. In this research, we experimentally examined one of the most recent case of the naming effect triggered by President Donald Trump, labeling COVID-19 as "Chinese Virus". Our results show that: (1) the "Chinese Virus" label increased stigmatization against Chinese immigrants by 5.66\%, while the effect is not statistically significant; (2) Stigmatization and xenophobia against Chinese immigrants were not considered as socially undesirable, compared with xenophobia against other groups in the U.S; (3) The "Chinese Virus" label significantly increased stigmatization against Chinese immigrants within groups of Democrats $(21.47 \%)$ liberals $(16.73 \%)$ and whites (19.93\%); (4) In spite of trivial treatment effect of the "Chinese Virus" label,

\footnotetext{
${ }^{1}$ https://news.gallup.com/poll/275792/remained-center-right-ideologically-2019.aspx

${ }^{2}$ https://news.gallup.com/poll/15370/party-affiliation.aspx
} 
stigmatization against Chinese immigrants remains at the same high level among conservatives and Republicans; (5) The "Chinese Virus" label did not influence people's perceived blameworthiness of the federal government in the outbreak of COVID-19.

Although with limitations, our findings provide important empirical support for WHO's guidelines for naming newly discovered diseases. In addition, we suggest the government authorities and mass media to be more cautious when releasing inconclusive information and discussion about the geographic or biological origin of the disease. It is important to note that the discussion on the origin of COVID-19 may have stigmatized Chinese communities even before the Trump's mislabel, while so far there is still no conclusive evidence showing the origin of COVID-19. Finally, we call for more research on the long-term effect of the mislabel and psychological and behavioral strategies to counter stigmatization and discrimination.

\section{References}

Aronow, P. M., Coppock, A., Crawford, F. W., \& Green, D. P. (2015). Combining list experiment and direct question estimates of sensitive behavior prevalence. Journal of Survey Statistics and Methodology, 3(1), 43-66.

Badger, E., \& Quealy, K. (2020, March 21). Red vs. blue on coronavirous concern: The gap is still big but closing. Retrieved from https://www.nytimes.com/interactive/2020/ 03/21/upshot/coronavirus-public-opinion.html

Blair, G., \& Imai, K. (2012). Statistical analysis of list experiments. Political Analysis, $20(1), 47-77$.

Coffman, K. B., Coffman, L. C., \& Ericson, K. M. M. (2017). The size of the lgbt population and the magnitude of antigay sentiment are substantially underestimated. Management Science, 63(10), 3168-3186.

Deville, J.-C., Särndal, C.-E., \& Sautory, O. (1993). Generalized raking procedures in survey sampling. Journal of the American statistical Association, 88(423), 1013-1020.

Fukuda, K., Wang, R., \& Vallat, B. (2015). Naming diseases: First do no harm. Science, 348(6235), 643-643. Retrieved from https://science.sciencemag.org/content/348/ 6235/643 doi: 10.1126/science.348.6235.643

Glynn, A. N. (2013). What can we learn with statistical truth serum? design and analysis of the list experiment. Public Opinion Quarterly, r7(S1), 159-172.

Graham, J., Haidt, J., \& Nosek, B. A. (2009). Liberals and conservatives rely on different sets of moral foundations. Journal of personality and social psychology, 96(5), 1029.

Greenbaum, Z. (2020, March 24). Countering stereotypes about asian americans. Retrieved from https://www.nytimes.com/2020/03/23/us/chinese-coronavirus -racist-attacks.html?searchResultPosition=10 
Imai, K. (2011). Multivariate regression analysis for the item count technique. Journal of the American Statistical Association, 106(494), 407-416.

Jacoby, A., Snape, D., \& Baker, G. A. (2005). Epilepsy and social identity: the stigma of a chronic neurological disorder. The Lancet Neurology, 4(3), 171-178.

James, O., Jilke, S., Petersen, C., \& Van de Walle, S. (2016). Citizens' blame of politicians for public service failure: Experimental evidence about blame reduction through delegation and contracting. Public Administration Review, 76(1), 83-93.

Kahan, D. M., Peters, E., Wittlin, M., Slovic, P., Ouellette, L. L., Braman, D., \& Mandel, G. (2012). The polarizing impact of science literacy and numeracy on perceived climate change risks. Nature climate change, 2(10), 732-735.

Kim, S. Y., Wang, Y., Deng, S., Alvarez, R., \& Li, J. (2011). Accent, perpetual foreigner stereotype, and perceived discrimination as indirect links between english proficiency and depressive symptoms in chinese american adolescents. Developmental psychology, 47(1), 289.

Kteily, N., Hodson, G., \& Bruneau, E. (2016). They see us as less than human: Metadehumanization predicts intergroup conflict via reciprocal dehumanization. Journal of Personality and Social Psychology, $110(3), 343$.

Major, B., \& O’brien, L. T. (2005). The social psychology of stigma. Annu. Rev. Psychol., $56,393-421$.

Miller, J. D. (1984). A new survey technique for studying deviant behavior. George Washington University.

Rogers, K., Jakes, L., \& Swanson, A. (2020, March 19). Trump defends using 'chinese virus' label, ignoring growing criticism. Retrieved from https://www.nytimes.com/2020/03/ 18/us/politics/china-virus.html?searchResultPosition=21

Stangor, C., \& Crandall, C. S. (2000). Threat and the social construction of stigma. The social psychology of stigma, 62.

Tavernise, S., \& Oppel Jr., R. A. (2020, March 24). Spit on, yelled at, attached: Chineseamericans fear for their safety. Retrieved from https://www.nytimes.com/2020/03/23/ us/chinese-coronavirus-racist-attacks.html?searchResultPosition=10

Van Bavel, J. J., \& Pereira, A. (2018). The partisan brain: An identity-based model of political belief. Trends in cognitive sciences, 22(3), 213-224. 


\section{Supplemental Information}

\section{Appendix 1 Characteristics of sample}

\begin{tabular}{|c|c|c|c|c|c|c|c|c|c|c|}
\hline & & & \multicolumn{4}{|c|}{ COVID-19 } & \multicolumn{4}{|c|}{ Chinese Virus } \\
\hline & \multicolumn{2}{|c|}{ Full Sample } & \multicolumn{2}{|c|}{ 3-item } & \multicolumn{2}{|l|}{ 4-item } & \multicolumn{2}{|c|}{ 3-item } & \multicolumn{2}{|l|}{4 -item } \\
\hline & Frequency & $\%$ & Frequency & $\%$ & Frequency & $\%$ & Frequency & $\%$ & Frequency & $\%$ \\
\hline Male & 559.00 & 46.58 & 152.00 & 51.18 & 144.00 & 47.21 & 125.00 & 42.81 & 138.00 & 45.10 \\
\hline Female & 641.00 & 53.42 & 145.00 & 48.82 & 161.00 & 52.79 & 167.00 & 57.19 & 168.00 & 54.90 \\
\hline Age: $18-29$ & 343.00 & 28.58 & 88.00 & 29.63 & 85.00 & 27.87 & 84.00 & 28.77 & 86.00 & 28.10 \\
\hline Age: $30-49$ & 607.00 & 50.58 & 148.00 & 49.83 & 156.00 & 51.15 & 153.00 & 52.40 & 150.00 & 49.02 \\
\hline Age: 50 and older & 250.00 & 20.83 & 61.00 & 20.54 & 64.00 & 20.98 & 55.00 & 18.84 & 70.00 & 22.88 \\
\hline White & 923.00 & 76.92 & 222.00 & 74.75 & 227.00 & 74.43 & 224.00 & 76.71 & 250.00 & 81.70 \\
\hline Black & 95.00 & 7.92 & 22.00 & 7.41 & 25.00 & 8.20 & 27.00 & 9.25 & 21.00 & 6.86 \\
\hline Hispanic & 70.00 & 5.83 & 20.00 & 6.73 & 20.00 & 6.56 & 17.00 & 5.82 & 13.00 & 4.25 \\
\hline Asian & 92.00 & 7.67 & 26.00 & 8.75 & 27.00 & 8.85 & 19.00 & 6.51 & 20.00 & 6.54 \\
\hline Other & 20.00 & 1.67 & 7.00 & 2.36 & 6.00 & 1.97 & 5.00 & 1.71 & 2.00 & 0.65 \\
\hline COVID-19: worried & 973.00 & 81.08 & 243.00 & 81.82 & 245.00 & 80.33 & 238.00 & 81.51 & 247.00 & 80.72 \\
\hline COVID-19: not worried & 227.00 & 18.92 & 54.00 & 18.18 & 60.00 & 19.67 & 54.00 & 18.49 & 59.00 & 19.28 \\
\hline$\geqq$ half time Twitter/Facebook & 609.00 & 50.75 & 165.00 & 55.56 & 139.00 & 45.57 & 152.00 & 52.05 & 153.00 & 50.00 \\
\hline$\overline{<}$ half time Twitter/Facebook & 591.00 & 49.25 & 132.00 & 44.44 & 166.00 & 54.43 & 140.00 & 47.95 & 153.00 & 50.00 \\
\hline Party: Democrat & 545.00 & 45.42 & 133.00 & 44.78 & 126.00 & 41.31 & 140.00 & 47.95 & 146.00 & 47.71 \\
\hline Party: Republican & 292.00 & 24.33 & 64.00 & 21.55 & 89.00 & 29.18 & 65.00 & 22.26 & 74.00 & 24.18 \\
\hline Party: Independent & 363.00 & 30.25 & 100.00 & 33.67 & 90.00 & 29.51 & 87.00 & 29.79 & 86.00 & 28.10 \\
\hline Ideology: conservative & 287.00 & 23.92 & 69.00 & 23.23 & 83.00 & 27.21 & 64.00 & 21.92 & 71.00 & 23.20 \\
\hline Ideology: moderate & 303.00 & 25.25 & 84.00 & 28.28 & 76.00 & 24.92 & 73.00 & 25.00 & 70.00 & 22.88 \\
\hline Ideology: liberal & 587.00 & 48.92 & 138.00 & 46.46 & 138.00 & 45.25 & 149.00 & 51.03 & 162.00 & 52.94 \\
\hline Ideology: no opinion & 23.00 & 1.92 & 6.00 & 2.02 & 8.00 & 2.62 & 6.00 & 2.05 & 3.00 & 0.98 \\
\hline Income: Less than $\$ 25,000$ & 196.00 & 16.33 & 52.00 & 17.51 & 45.00 & 14.75 & 55.00 & 18.84 & 44.00 & 14.38 \\
\hline Income: $\$ 25,000$ to $\$ 74,999$ & 602.00 & 50.17 & 147.00 & 49.49 & 164.00 & 53.77 & 137.00 & 46.92 & 154.00 & 50.33 \\
\hline Income: $\$ 75,000$ or more & 402.00 & 33.50 & 98.00 & 33.00 & 96.00 & 31.48 & 100.00 & 34.25 & 108.00 & 35.29 \\
\hline
\end{tabular}




\section{Appendix 2 True stigmatization}

COVID indicates the respondents in the COVID-19 group. CV indicates the respondents in the Chinese Virus group. MC indicates the respondents who have successfully passed the manipulation checks.

\begin{tabular}{|c|c|c|c|c|c|c|c|c|}
\hline \multirow[b]{2}{*}{ List: 4-item } & \multicolumn{2}{|c|}{ Original COVID } & \multicolumn{2}{|c|}{ Original CV } & \multirow{2}{*}{$\begin{array}{c}\text { COVID Weighted } \\
0.211^{* *} \\
(0.083)\end{array}$} & \multirow{2}{*}{$\begin{array}{c}\text { CV Weighted } \\
0.219^{* * *} \\
(0.075)\end{array}$} & \multirow{2}{*}{$\begin{array}{r}\text { COVID MC } \\
0.157^{* *} \\
(0.065)\end{array}$} & \multirow{2}{*}{$\begin{array}{c}\text { CV MC } \\
0.236^{* * * *} \\
(0.070)\end{array}$} \\
\hline & $\begin{array}{l}0.137^{* *} \\
(0.063)\end{array}$ & $\begin{array}{l}0.158^{* *} \\
(0.065)\end{array}$ & $\begin{array}{l}0.194^{* * *} \\
(0.064)\end{array}$ & $\begin{array}{l}0.229^{* * *} \\
(0.066)\end{array}$ & & & & \\
\hline Male & & $\begin{array}{c}0.088 \\
(0.066)\end{array}$ & & $\begin{array}{c}-0.011 \\
(0.068)\end{array}$ & $\begin{array}{c}0.125 \\
(0.084)\end{array}$ & $\begin{array}{c}-0.020 \\
(0.077)\end{array}$ & $\begin{array}{c}0.094 \\
(0.066)\end{array}$ & $\begin{array}{c}-0.022 \\
(0.073)\end{array}$ \\
\hline White & & $\begin{array}{c}-0.169^{* *} \\
(0.080)\end{array}$ & & $\begin{array}{r}-0.027 \\
(0.089)\end{array}$ & $\begin{array}{l}-0.271^{* * * *} \\
(0.103)\end{array}$ & $\begin{array}{c}0.069 \\
(0.102)\end{array}$ & $\begin{array}{c}-0.166^{* *} \\
(0.080)\end{array}$ & $\begin{array}{c}-0.088 \\
(0.097)\end{array}$ \\
\hline Age & & $\begin{array}{c}-0.002 \\
(0.003)\end{array}$ & & $\begin{array}{r}-0.005^{*} \\
(0.003)\end{array}$ & $\begin{array}{c}-0.002 \\
(0.003)\end{array}$ & $\begin{array}{r}-0.005^{*} \\
(0.003)\end{array}$ & $\begin{array}{c}-0.002 \\
(0.003)\end{array}$ & $\begin{array}{c}-0.004 \\
(0.003)\end{array}$ \\
\hline Income & & $\begin{array}{c}0.001 \\
(0.019)\end{array}$ & & $\begin{array}{c}0.005 \\
(0.019)\end{array}$ & $\begin{array}{c}-0.005 \\
(0.024)\end{array}$ & $\begin{array}{c}-0.0001 \\
(0.022)\end{array}$ & $\begin{array}{c}-0.0003 \\
(0.019)\end{array}$ & $\begin{array}{c}0.014 \\
(0.020)\end{array}$ \\
\hline Worry level & & $\begin{array}{r}0.081^{*} \\
(0.043)\end{array}$ & & $\begin{array}{r}0.077^{*} \\
(0.042)\end{array}$ & $\begin{array}{c}0.086 \\
(0.055)\end{array}$ & $\begin{array}{l}0.101^{* *} \\
(0.048)\end{array}$ & $\begin{array}{r}0.074^{*} \\
(0.043)\end{array}$ & $\begin{array}{c}0.073 \\
(0.045)\end{array}$ \\
\hline Read news on Facebook/Twitter & & $\begin{array}{l}0.110^{* * * *} \\
(0.024)\end{array}$ & & $\begin{array}{l}0.065^{* *} \\
(0.026)\end{array}$ & $\begin{array}{l}0.097^{* * *} \\
(0.031)\end{array}$ & $\begin{array}{l}0.061^{* *} \\
(0.030)\end{array}$ & $\begin{array}{l}0.108^{* * *} \\
(0.024)\end{array}$ & $\begin{array}{l}0.062^{* *} \\
(0.028)\end{array}$ \\
\hline Party: Independent & & $\begin{array}{c}0.048 \\
(0.093)\end{array}$ & & $\begin{array}{c}-0.116 \\
(0.094)\end{array}$ & $\begin{array}{c}-0.044 \\
(0.119)\end{array}$ & $\begin{array}{r}-0.147 \\
(0.108)\end{array}$ & $\begin{array}{c}0.046 \\
(0.093)\end{array}$ & $\begin{array}{c}-0.138 \\
(0.104)\end{array}$ \\
\hline Party: Republican & & $\begin{array}{c}0.141 \\
(0.124)\end{array}$ & & $\begin{array}{c}0.034 \\
(0.130)\end{array}$ & $\begin{array}{c}0.052 \\
(0.159)\end{array}$ & $\begin{array}{c}0.025 \\
(0.149)\end{array}$ & $\begin{array}{c}0.142 \\
(0.124)\end{array}$ & $\begin{array}{c}0.067 \\
(0.144)\end{array}$ \\
\hline Moderate & & $\begin{array}{c}-0.118 \\
(0.109)\end{array}$ & & $\begin{array}{c}-0.090 \\
(0.121)\end{array}$ & $\begin{array}{l}-0.481^{* * *} \\
(0.140)\end{array}$ & $\begin{array}{c}-0.436^{* * *} \\
(0.139)\end{array}$ & $\begin{array}{r}-0.102 \\
(0.110)\end{array}$ & $\begin{array}{r}-0.077 \\
(0.132)\end{array}$ \\
\hline Liberal & & $\begin{array}{c}-0.080 \\
(0.122)\end{array}$ & & $\begin{array}{c}-0.262^{* *} \\
(0.131)\end{array}$ & $\begin{array}{l}-1.874^{* * *} \\
(0.157)\end{array}$ & $\begin{array}{l}-2.007^{* * *} \\
(0.150)\end{array}$ & $\begin{array}{c}-0.073 \\
(0.123)\end{array}$ & $\begin{array}{c}-0.292^{* *} \\
(0.146)\end{array}$ \\
\hline No opinion & & $\begin{array}{c}0.005 \\
(0.231)\end{array}$ & & $\begin{array}{c}-0.192 \\
(0.307)\end{array}$ & $\begin{array}{l}0.976^{* * *} \\
(0.296)\end{array}$ & $\begin{array}{c}0.217 \\
(0.352)\end{array}$ & $\begin{array}{c}0.017 \\
(0.232)\end{array}$ & $\begin{array}{c}0.008 \\
(0.351)\end{array}$ \\
\hline Constant & $\begin{array}{l}1.519^{* * *} \\
(0.045)\end{array}$ & $\begin{array}{l}1.677^{* * *} \\
(0.587)\end{array}$ & $\begin{array}{l}1.479^{* * *} \\
(0.046)\end{array}$ & $\begin{array}{c}0.962 \\
(0.801)\end{array}$ & $\begin{array}{l}2.976^{* * *} \\
(0.752)\end{array}$ & $\begin{array}{c}1.427 \\
(0.918)\end{array}$ & $\begin{array}{l}1.689^{* * *} \\
(0.588)\end{array}$ & $\begin{array}{l}1.516^{* * *} \\
(0.350)\end{array}$ \\
\hline State Fixed effects & No & Yes & No & Yes & Yes & Yes & Yes & Yes \\
\hline $\begin{array}{l}\mathrm{N} \\
\mathrm{R}^{2}\end{array}$ & $\begin{array}{c}602 \\
0.008\end{array}$ & $\begin{array}{c}602 \\
0.156\end{array}$ & $\begin{array}{c}598 \\
0.015\end{array}$ & $\begin{array}{c}598 \\
0.145\end{array}$ & $\begin{array}{c}602 \\
0.512\end{array}$ & $\begin{array}{c}598 \\
0.560\end{array}$ & $\begin{array}{c}599 \\
0.154\end{array}$ & $\begin{array}{c}515 \\
0.152\end{array}$ \\
\hline
\end{tabular}

Notes: Standard errors are in brackets. For the State fixed effect models, standard errors are clustered at the State level.

${ }^{*} \mathrm{p}<.1 ;{ }^{* *} \mathrm{p}<.05 ;{ }^{* * *} \mathrm{p}<.01$ 


\section{Appendix 3 Maximum likelihood estimated proportion}

True stigmatization in full sample and subgroups. The vertical bars indicate $95 \%$ confidence intervals.
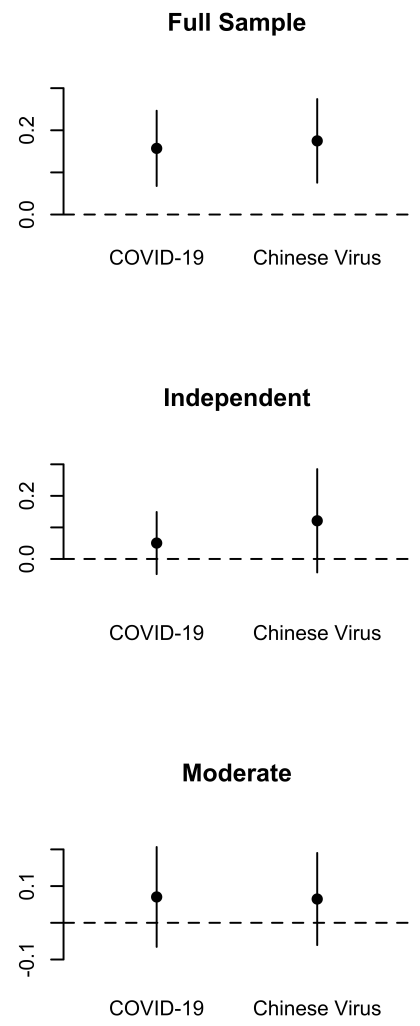

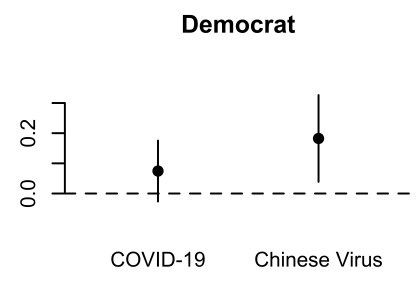

Liberal

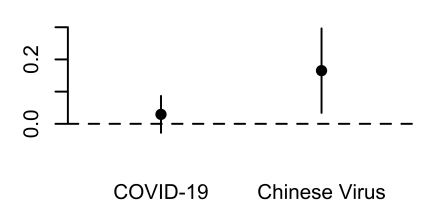

White

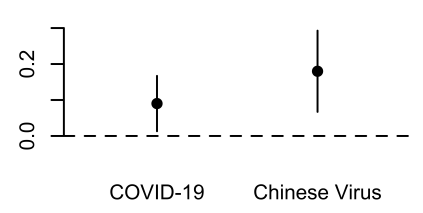

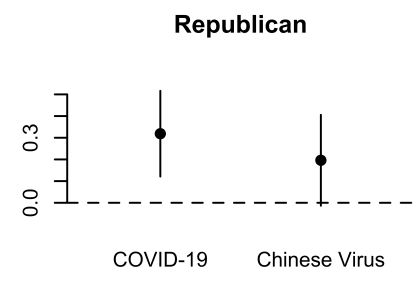
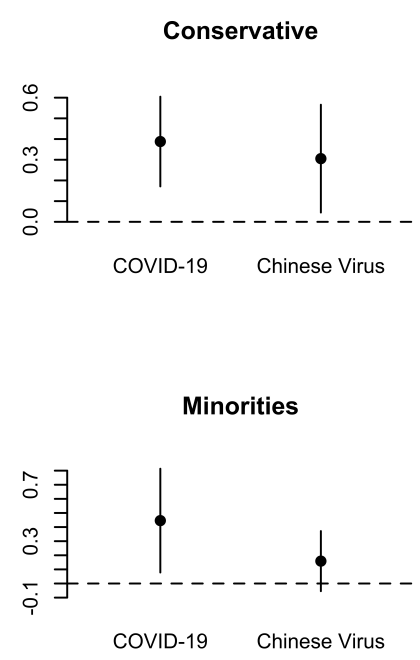


\section{Appendix 4 Blameworthiness of the federal government}

MC indicates the respondents who have successfully passed the manipulation checks.

\begin{tabular}{|c|c|c|c|c|}
\hline \multirow[b]{2}{*}{ Chinese Virus } & \multicolumn{2}{|c|}{ Original Data } & \multirow{2}{*}{$\begin{array}{c}\text { Weighted } \\
0.724 \\
(1.928)\end{array}$} & \multirow{2}{*}{$\begin{array}{c}\mathrm{MC} \\
-0.588 \\
(1.681)\end{array}$} \\
\hline & $\begin{array}{c}0.987 \\
(1.808)\end{array}$ & $\begin{array}{c}0.551 \\
(1.640)\end{array}$ & & \\
\hline Male & & $\begin{array}{c}2.138 \\
(1.677)\end{array}$ & $\begin{array}{c}0.764 \\
(1.973)\end{array}$ & $\begin{array}{c}1.711 \\
(1.719)\end{array}$ \\
\hline White & & $\begin{array}{c}-1.878 \\
(2.097)\end{array}$ & $\begin{array}{c}-2.298 \\
(2.466)\end{array}$ & $\begin{array}{c}-2.391 \\
(2.164)\end{array}$ \\
\hline Age & & $\begin{array}{c}-0.272^{* * *} \\
(0.066)\end{array}$ & $\begin{array}{l}-0.365^{* * *} \\
(0.078)\end{array}$ & $\begin{array}{l}-0.268^{* * *} \\
(0.067)\end{array}$ \\
\hline Income & & $\begin{array}{c}0.365 \\
(0.479)\end{array}$ & $\begin{array}{c}0.633 \\
(0.564)\end{array}$ & $\begin{array}{c}0.563 \\
(0.492)\end{array}$ \\
\hline Worry level & & $\begin{array}{l}4.002^{* * *} \\
(1.065)\end{array}$ & $\begin{array}{l}4.038^{* * *} \\
(1.253)\end{array}$ & $\begin{array}{l}3.709^{* * *} \\
(1.102)\end{array}$ \\
\hline Read news on Facebook/Twitter & & $\begin{array}{l}1.098^{*} \\
(0.635)\end{array}$ & $\begin{array}{l}1.862^{* *} \\
(0.747)\end{array}$ & $\begin{array}{c}0.936 \\
(0.649)\end{array}$ \\
\hline Moderate & & $\begin{array}{l}7.947^{* * *} \\
(2.887)\end{array}$ & $\begin{array}{c}6.585^{*} \\
(3.395)\end{array}$ & $\begin{array}{l}9.023^{* * *} \\
(2.968)\end{array}$ \\
\hline Liberal & & $\begin{array}{l}17.225^{* * *} \\
(3.200)\end{array}$ & $\begin{array}{c}-34.196^{* * *} \\
(3.764)\end{array}$ & $\begin{array}{l}18.462^{* * *} \\
(3.331)\end{array}$ \\
\hline No opinion & & $\begin{array}{l}17.248^{* * *} \\
(6.561)\end{array}$ & $\begin{array}{l}60.227^{* * *} \\
(7.717)\end{array}$ & $\begin{array}{l}23.120^{* * *} \\
(6.799)\end{array}$ \\
\hline Party: Independent & & $\begin{array}{c}-4.740^{* *} \\
(2.374)\end{array}$ & $\begin{array}{c}-5.165^{*} \\
(2.792)\end{array}$ & $\begin{array}{c}-4.913^{* *} \\
(2.460)\end{array}$ \\
\hline Party: Republican & & $\begin{array}{l}-15.159^{* * *} \\
(3.224)\end{array}$ & $\begin{array}{l}-19.419^{* * *} \\
(3.791)\end{array}$ & $\begin{array}{l}-16.158^{* * *} \\
(3.346)\end{array}$ \\
\hline Constant & $\begin{array}{l}49.383^{* * *} \\
(1.277)\end{array}$ & $\begin{array}{l}47.168^{* * *} \\
(17.107)\end{array}$ & $\begin{array}{l}72.393^{* * *} \\
(20.121)\end{array}$ & $\begin{array}{l}60.781^{* * *} \\
(20.380)\end{array}$ \\
\hline State Fixed effects & No & Yes & Yes & Yes \\
\hline $\mathrm{N}$ & 1,199 & 1,199 & 1,199 & 1,113 \\
\hline $\mathrm{R}^{2}$ & 0.0002 & 0.252 & 0.302 & 0.276 \\
\hline
\end{tabular}

Notes: Standard errors are in brackets. For the State fixed effect models, standard errors are clustered at the State level. ${ }^{*} \mathrm{p}<.1 ;{ }^{* *} \mathrm{p}<.05 ;{ }^{* * *} \mathrm{p}<.01$ 


\section{Appendix 5 Direct stigmatization}

MC indicates the respondents who have successfully passed the manipulation checks.

\begin{tabular}{|c|c|c|c|c|}
\hline \multirow[b]{2}{*}{ Chinese Virus } & \multicolumn{2}{|c|}{$\begin{array}{c}\text { Original Data } \\
\text { logistic }\end{array}$} & \multirow{2}{*}{$\begin{array}{c}\text { Weighted } \\
\text { OLS } \\
0.022 \\
(0.037)\end{array}$} & \multirow{2}{*}{$\begin{array}{c}\mathrm{MC} \\
\text { logistic } \\
0.108 \\
(0.295)\end{array}$} \\
\hline & $\begin{array}{c}0.106 \\
(0.239)\end{array}$ & $\begin{array}{c}0.242 \\
(0.272)\end{array}$ & & \\
\hline Male & & $\begin{array}{c}0.188 \\
(0.279)\end{array}$ & $\begin{array}{c}0.027 \\
(0.038)\end{array}$ & $\begin{array}{c}-0.037 \\
(0.300)\end{array}$ \\
\hline White & & $\begin{array}{c}0.115 \\
(0.340)\end{array}$ & $\begin{array}{c}0.034 \\
(0.046)\end{array}$ & $\begin{array}{c}0.206 \\
(0.374)\end{array}$ \\
\hline Age & & $\begin{array}{c}-0.005 \\
(0.011)\end{array}$ & $\begin{array}{c}-0.002 \\
(0.002)\end{array}$ & $\begin{array}{c}-0.002 \\
(0.012)\end{array}$ \\
\hline Income & & $\begin{array}{c}-0.211^{* *} \\
(0.084)\end{array}$ & $\begin{array}{c}-0.026^{* *} \\
(0.011)\end{array}$ & $\begin{array}{c}-0.162^{*} \\
(0.088)\end{array}$ \\
\hline Worry level & & $\begin{array}{c}0.022 \\
(0.177)\end{array}$ & $\begin{array}{c}0.017 \\
(0.024)\end{array}$ & $\begin{array}{c}-0.018 \\
(0.191)\end{array}$ \\
\hline Read news on Facebook/Twitter & & $\begin{array}{l}0.354^{* * *} \\
(0.110)\end{array}$ & $\begin{array}{l}0.047^{* * *} \\
(0.015)\end{array}$ & $\begin{array}{l}0.372^{* * *} \\
(0.119)\end{array}$ \\
\hline Moderate & & $\begin{array}{c}-0.458 \\
(0.406)\end{array}$ & $\begin{array}{l}-0.146^{* *} \\
(0.063)\end{array}$ & $\begin{array}{c}-0.672 \\
(0.440)\end{array}$ \\
\hline Liberal & & $\begin{array}{l}-1.151^{* *} \\
(0.480)\end{array}$ & $\begin{array}{l}-0.314^{* * *} \\
(0.069)\end{array}$ & $\begin{array}{l}-1.672^{* * *} \\
(0.549)\end{array}$ \\
\hline No opinion & & $\begin{array}{c}-0.270 \\
(0.961)\end{array}$ & $\begin{array}{c}-0.005 \\
(0.147)\end{array}$ & $\begin{array}{c}-0.221 \\
(1.000)\end{array}$ \\
\hline Party: Independent & & $\begin{array}{c}0.196 \\
(0.402)\end{array}$ & $\begin{array}{c}0.027 \\
(0.052)\end{array}$ & $\begin{array}{c}0.143 \\
(0.449)\end{array}$ \\
\hline Party: Republican & & $\begin{array}{c}0.509 \\
(0.468)\end{array}$ & $\begin{array}{c}0.054 \\
(0.070)\end{array}$ & $\begin{array}{c}-0.015 \\
(0.523)\end{array}$ \\
\hline Constant & $\begin{array}{c}-1.889^{* * *} \\
(0.172)\end{array}$ & $\begin{array}{c}-18.329 \\
(6,522.638)\end{array}$ & $\begin{array}{c}0.051 \\
(0.446)\end{array}$ & $\begin{array}{c}-1.524 \\
(1.415)\end{array}$ \\
\hline $\begin{array}{l}\text { State Fixed effects } \\
\mathrm{N}\end{array}$ & $\begin{array}{l}\text { No } \\
589\end{array}$ & $\begin{array}{l}Y e s \\
589\end{array}$ & $\begin{array}{l}Y e s \\
589\end{array}$ & $\begin{array}{l}Y \text { Yes } \\
540\end{array}$ \\
\hline $\mathrm{R}^{2}$ & & & 0.184 & \\
\hline $\begin{array}{l}\text { Log Likelihood } \\
\text { AIC }\end{array}$ & $\begin{array}{c}-235.761 \\
475.521\end{array}$ & $\begin{array}{c}-193.486 \\
506.971\end{array}$ & & $\begin{array}{c}-166.759 \\
451.518\end{array}$ \\
\hline
\end{tabular}




\section{Appendix 6 Blameworthiness of the federal government: subgroups}

\begin{tabular}{|c|c|c|c|c|c|c|c|c|}
\hline & Democrat & Republican & Idependent & Liberal & Conservative & Moderate & White & Minorities \\
\hline Chinese Virus & $\begin{array}{r}-1.002 \\
(2.362)\end{array}$ & $\begin{array}{c}3.778 \\
(3.544)\end{array}$ & $\begin{array}{c}0.723 \\
(3.404)\end{array}$ & $\begin{array}{r}-0.017 \\
(2.213)\end{array}$ & $\begin{array}{c}2.597 \\
(3.596)\end{array}$ & $\begin{array}{r}-4.076 \\
(3.655)\end{array}$ & $\begin{array}{c}2.623 \\
(1.869)\end{array}$ & $\begin{array}{r}-5.408 \\
(3.791)\end{array}$ \\
\hline Male & $\begin{array}{c}2.514 \\
(2.467)\end{array}$ & $\begin{array}{c}0.756 \\
(3.556)\end{array}$ & $\begin{array}{c}-0.167 \\
(3.300)\end{array}$ & $\begin{array}{r}3.955^{*} \\
(2.303)\end{array}$ & $\begin{array}{c}-4.189 \\
(3.559)\end{array}$ & $\begin{array}{c}-0.579 \\
(3.523)\end{array}$ & $\begin{array}{c}2.544 \\
(1.914)\end{array}$ & $\begin{array}{c}-2.093 \\
(3.686)\end{array}$ \\
\hline White & $\begin{array}{c}-0.899 \\
(2.805)\end{array}$ & $\begin{array}{c}-9.249 \\
(5.807)\end{array}$ & $\begin{array}{c}-3.042 \\
(4.225)\end{array}$ & $\begin{array}{r}-2.657 \\
(2.646)\end{array}$ & $\begin{array}{r}-7.317 \\
(5.709)\end{array}$ & $\begin{array}{c}3.219 \\
(4.521)\end{array}$ & & \\
\hline Age & $\begin{array}{c}-0.074 \\
(0.095)\end{array}$ & $\begin{array}{c}-0.614^{* * *} \\
(0.142)\end{array}$ & $\begin{array}{c}-0.235 \\
(0.143)\end{array}$ & $\begin{array}{c}-0.055 \\
(0.089)\end{array}$ & $\begin{array}{c}-0.665^{* * *} \\
(0.134)\end{array}$ & $\begin{array}{c}-0.405^{* * *} \\
(0.151)\end{array}$ & $\begin{array}{c}-0.281^{* * *} \\
(0.072)\end{array}$ & $\begin{array}{c}-0.257 \\
(0.174)\end{array}$ \\
\hline Income & $\begin{array}{c}0.778 \\
(0.683)\end{array}$ & $\begin{array}{c}0.029 \\
(1.069)\end{array}$ & $\begin{array}{c}0.320 \\
(0.990)\end{array}$ & $\begin{array}{c}-0.073 \\
(0.640)\end{array}$ & $\begin{array}{c}1.071 \\
(1.036)\end{array}$ & $\begin{array}{c}0.548 \\
(1.047)\end{array}$ & $\begin{array}{c}-0.174 \\
(0.544)\end{array}$ & $\begin{array}{l}2.773^{\text {*** }} \\
(1.054)\end{array}$ \\
\hline Worry level & $\begin{array}{l}6.529^{* * *} \\
(1.708)\end{array}$ & $\begin{array}{c}2.634 \\
(2.174)\end{array}$ & $\begin{array}{c}2.053 \\
(2.008)\end{array}$ & $\begin{array}{l}4.939^{* * *} \\
(1.569)\end{array}$ & $\begin{array}{c}1.083 \\
(2.153)\end{array}$ & $\begin{array}{l}5.002^{* *} \\
(2.181)\end{array}$ & $\begin{array}{c}2.841^{* *} \\
(1.245)\end{array}$ & $\begin{array}{l}6.769^{\text {*** }} \\
(2.192)\end{array}$ \\
\hline Read news on Facebook/Twitter & $\begin{array}{c}0.374 \\
(0.924)\end{array}$ & $\begin{array}{r}2.323^{*} \\
(1.391)\end{array}$ & $\begin{array}{c}0.867 \\
(1.305)\end{array}$ & $\begin{array}{c}-0.475 \\
(0.842)\end{array}$ & $\begin{array}{c}3.056^{* *} \\
(1.403)\end{array}$ & $\begin{array}{c}2.262 \\
(1.427)\end{array}$ & $\begin{array}{r}1.305^{*} \\
(0.736)\end{array}$ & $\begin{array}{c}-1.073 \\
(1.391)\end{array}$ \\
\hline Moderate & $\begin{array}{c}-2.109 \\
(8.333)\end{array}$ & $\begin{array}{l}12.392^{\text {*** }} \\
(4.565)\end{array}$ & $\begin{array}{c}5.673 \\
(5.115)\end{array}$ & & & & $\begin{array}{l}9.058^{* * *} \\
(3.211)\end{array}$ & $\begin{array}{c}2.701 \\
(6.803)\end{array}$ \\
\hline Liberal & $\begin{array}{c}2.870 \\
(7.552)\end{array}$ & $\begin{array}{l}11.990 \\
(8.851)\end{array}$ & $\begin{array}{l}21.041^{* * *} \\
(5.571)\end{array}$ & & & & $\begin{array}{l}19.265^{* * *} \\
(3.643)\end{array}$ & $\begin{array}{c}7.791 \\
(7.201)\end{array}$ \\
\hline No opinion & $\begin{array}{c}-17.719 \\
(20.939)\end{array}$ & $\begin{array}{c}26.708 \\
(21.955)\end{array}$ & $\begin{array}{l}14.955^{*} \\
(8.780)\end{array}$ & & & & $\begin{array}{l}16.451^{* *} \\
(7.621)\end{array}$ & $\begin{array}{c}16.902 \\
(13.633)\end{array}$ \\
\hline Party: Independent & & & & $\begin{array}{c}-1.890 \\
(2.982)\end{array}$ & $\begin{array}{r}-17.680^{*} \\
(9.091)\end{array}$ & $\begin{array}{c}-6.767 \\
(4.751)\end{array}$ & $\begin{array}{r}-5.401^{*} \\
(2.807)\end{array}$ & $\begin{array}{c}-6.512 \\
(4.743)\end{array}$ \\
\hline Party: Republican & & & & $\begin{array}{c}-16.407^{* *} \\
(7.827)\end{array}$ & $\begin{array}{c}-31.584^{* * *} \\
(8.288)\end{array}$ & $\begin{array}{c}-12.215^{* *} \\
(5.919)\end{array}$ & $\begin{array}{c}-15.356^{* * *} \\
(3.702)\end{array}$ & $\begin{array}{c}-15.380^{* *} \\
(7.126)\end{array}$ \\
\hline Constant & $\begin{array}{c}46.795^{\text {**** }} \\
(14.460)\end{array}$ & $\begin{array}{c}52.086^{\text {**** }} \\
(20.155)\end{array}$ & $\begin{array}{c}36.245^{\text {*** }} \\
(13.354)\end{array}$ & $\begin{array}{c}65.888^{* * *} \\
(10.847)\end{array}$ & $\begin{array}{l}77.321^{* * *} \\
(22.463)\end{array}$ & $\begin{array}{c}74.919^{* *} \\
(31.296)\end{array}$ & $\begin{array}{l}49.784^{* * *} \\
(17.312)\end{array}$ & $\begin{array}{c}40.577^{* *} \\
(19.328)\end{array}$ \\
\hline State Fixed effects & Yes & Yes & Yes & Yes & Yes & Yes & Yes & Yes \\
\hline $\mathrm{N}$ & 544 & 292 & 363 & 586 & 287 & 326 & 922 & 277 \\
\hline $\mathrm{R}^{2}$ & 0.136 & 0.293 & 0.201 & 0.131 & 0.340 & 0.224 & 0.283 & 0.312 \\
\hline
\end{tabular}

Notes: Standard errors are in brackets. For the State fixed effect models, standard errors are clustered at the State level.

${ }^{*} \mathrm{p}<.1 ;{ }^{* *} \mathrm{p}<.05 ;{ }^{* * *} \mathrm{p}<.01$ 


\section{Appendix 7 Direct stigmatization: subgroups}

\begin{tabular}{|c|c|c|c|c|c|c|c|c|}
\hline & Democrat & Republican & Idependent & Liberal & Conservative & Moderate & White & Minorities \\
\hline Chinese Virus & $\begin{array}{c}-0.038 \\
(0.502)\end{array}$ & $\begin{array}{c}1.825^{* *} \\
(0.840)\end{array}$ & $\begin{array}{c}-0.966 \\
(0.609)\end{array}$ & $\begin{array}{c}0.192 \\
(0.538)\end{array}$ & $\begin{array}{c}0.196 \\
(0.667)\end{array}$ & $\begin{array}{c}0.322 \\
(0.573)\end{array}$ & $\begin{array}{c}0.341 \\
(0.323)\end{array}$ & $\begin{array}{r}-0.939 \\
(0.902)\end{array}$ \\
\hline Male & $\begin{array}{c}-0.672 \\
(0.540)\end{array}$ & $\begin{array}{c}-0.157 \\
(0.715)\end{array}$ & $\begin{array}{l}1.253^{* *} \\
(0.628)\end{array}$ & $\begin{array}{c}0.157 \\
(0.547)\end{array}$ & $\begin{array}{c}-0.110 \\
(0.628)\end{array}$ & $\begin{array}{c}0.159 \\
(0.567)\end{array}$ & $\begin{array}{c}0.101 \\
(0.336)\end{array}$ & $\begin{array}{c}2.183^{* *} \\
(0.964)\end{array}$ \\
\hline White & $\begin{array}{c}0.126 \\
(0.607)\end{array}$ & $\begin{array}{c}0.562 \\
(1.060)\end{array}$ & $\begin{array}{c}-0.405 \\
(0.748)\end{array}$ & $\begin{array}{c}0.222 \\
(0.645)\end{array}$ & $\begin{array}{l}1.980^{* *} \\
(1.007)\end{array}$ & $\begin{array}{c}-0.660 \\
(0.664)\end{array}$ & & \\
\hline Age & $\begin{array}{c}0.012 \\
(0.020)\end{array}$ & $\begin{array}{c}-0.051^{*} \\
(0.030)\end{array}$ & $\begin{array}{c}0.010 \\
(0.028)\end{array}$ & $\begin{array}{c}0.015 \\
(0.022)\end{array}$ & $\begin{array}{c}-0.079^{* *} \\
(0.031)\end{array}$ & $\begin{array}{c}0.001 \\
(0.025)\end{array}$ & $\begin{array}{c}-0.008 \\
(0.013)\end{array}$ & $\begin{array}{c}-0.019 \\
(0.037)\end{array}$ \\
\hline Income & $\begin{array}{c}-0.127 \\
(0.143)\end{array}$ & $\begin{array}{c}-0.316 \\
(0.205)\end{array}$ & $\begin{array}{c}-0.103 \\
(0.206)\end{array}$ & $\begin{array}{c}-0.140 \\
(0.156)\end{array}$ & $\begin{array}{r}-0.319^{*} \\
(0.192)\end{array}$ & $\begin{array}{c}-0.275 \\
(0.173)\end{array}$ & $\begin{array}{c}-0.245^{\text {*** }} \\
(0.100)\end{array}$ & $\begin{array}{c}-0.290 \\
(0.246)\end{array}$ \\
\hline Worry level & $\begin{array}{c}-0.276 \\
(0.354)\end{array}$ & $\begin{array}{l}1.076^{*} \\
(0.575)\end{array}$ & $\begin{array}{c}-0.128 \\
(0.300)\end{array}$ & $\begin{array}{r}-0.644^{*} \\
(0.391)\end{array}$ & $\begin{array}{c}-0.050 \\
(0.424)\end{array}$ & $\begin{array}{c}0.164 \\
(0.349)\end{array}$ & $\begin{array}{c}0.116 \\
(0.216)\end{array}$ & $\begin{array}{c}-0.117 \\
(0.501)\end{array}$ \\
\hline Read news on Facebook/Twitter & $\begin{array}{c}0.169 \\
(0.196)\end{array}$ & $\begin{array}{c}0.235 \\
(0.311)\end{array}$ & $\begin{array}{l}0.702^{* * *} \\
(0.267)\end{array}$ & $\begin{array}{c}0.199 \\
(0.207)\end{array}$ & $\begin{array}{c}0.701^{* *} \\
(0.301)\end{array}$ & $\begin{array}{c}0.652^{* *} \\
(0.260)\end{array}$ & $\begin{array}{l}0.324^{* *} \\
(0.133)\end{array}$ & $\begin{array}{c}0.507 \\
(0.358)\end{array}$ \\
\hline Moderate & $\begin{array}{r}-2.635^{*} \\
(1.450)\end{array}$ & $\begin{array}{c}-1.584 \\
(1.046)\end{array}$ & $\begin{array}{c}-0.545 \\
(0.768)\end{array}$ & & & & $\begin{array}{r}-0.792^{*} \\
(0.461)\end{array}$ & $\begin{array}{c}0.886 \\
(1.498)\end{array}$ \\
\hline Liberal & $\begin{array}{c}-2.911^{* *} \\
(1.300)\end{array}$ & $\begin{array}{c}2.025 \\
(1.632)\end{array}$ & $\begin{array}{c}-3.154^{* *} \\
(1.361)\end{array}$ & & & & $\begin{array}{c}-1.363^{* *} \\
(0.573)\end{array}$ & $\begin{array}{c}-1.414 \\
(1.604)\end{array}$ \\
\hline No opinion & $\begin{array}{c}-2.269 \\
(13,424.560)\end{array}$ & & $\begin{array}{c}0.057 \\
(1.302)\end{array}$ & & & & $\begin{array}{c}-1.113 \\
(1.344)\end{array}$ & $\begin{array}{c}0.947 \\
(2.453)\end{array}$ \\
\hline Party: Independent & & & & $\begin{array}{r}-1.981^{*} \\
(1.204)\end{array}$ & $\begin{array}{c}0.182 \\
(1.255)\end{array}$ & $\begin{array}{c}1.171 \\
(0.783)\end{array}$ & $\begin{array}{c}0.188 \\
(0.511)\end{array}$ & $\begin{array}{c}0.197 \\
(1.111)\end{array}$ \\
\hline Party: Republican & & & & $\begin{array}{l}3.794^{* * *} \\
(1.152)\end{array}$ & $\begin{array}{c}-0.721 \\
(1.157)\end{array}$ & $\begin{array}{c}0.837 \\
(0.931)\end{array}$ & $\begin{array}{c}0.494 \\
(0.558)\end{array}$ & $\begin{array}{c}1.090 \\
(1.377)\end{array}$ \\
\hline Constant & $\begin{array}{c}2.162 \\
(2.141)\end{array}$ & $\begin{array}{c}-20.212 \\
(10,754.010)\end{array}$ & $\begin{array}{c}-19.219 \\
(3,896.462)\end{array}$ & $\begin{array}{c}-0.120 \\
(1.883)\end{array}$ & $\begin{array}{c}-16.249 \\
(10,754.010)\end{array}$ & $\begin{array}{c}-21.037 \\
(4,965.977)\end{array}$ & $\begin{array}{c}-18.147 \\
(6,522.639)\end{array}$ & $\begin{array}{c}-19.728 \\
(17,730.370)\end{array}$ \\
\hline State Fixed effects & Yes & Yes & Yes & Yes & Yes & Yes & Yes & Yes \\
\hline $\mathrm{N}$ & 273 & 129 & 187 & 287 & 133 & 169 & 446 & 143 \\
\hline Log Likelihood & -60.834 & -35.604 & -46.825 & -54.997 & -43.364 & -49.597 & -140.534 & -28.771 \\
\hline $\mathrm{AIC}$ & 221.668 & 165.208 & 189.650 & 209.994 & 180.729 & 197.194 & 397.067 & 151.541 \\
\hline
\end{tabular}

Notes: Standard errors are in brackets. For the State fixed effect models, standard errors are clustered at the State level.

${ }^{*} \mathrm{p}<.1 ;{ }^{* *} \mathrm{p}<.05 ;{ }^{* * *} \mathrm{p}<.01$ 


\section{Appendix 8 Survey instruments}

[Survey begin]

[VPN and Proxy Check]

[IRB Consent Form]

In this study, we invite you to share your opinion of the federal government's response to the current epidemic outbreak.

[COVID-19 Condition] Please read the post below and answer following questions with this post in your mind.

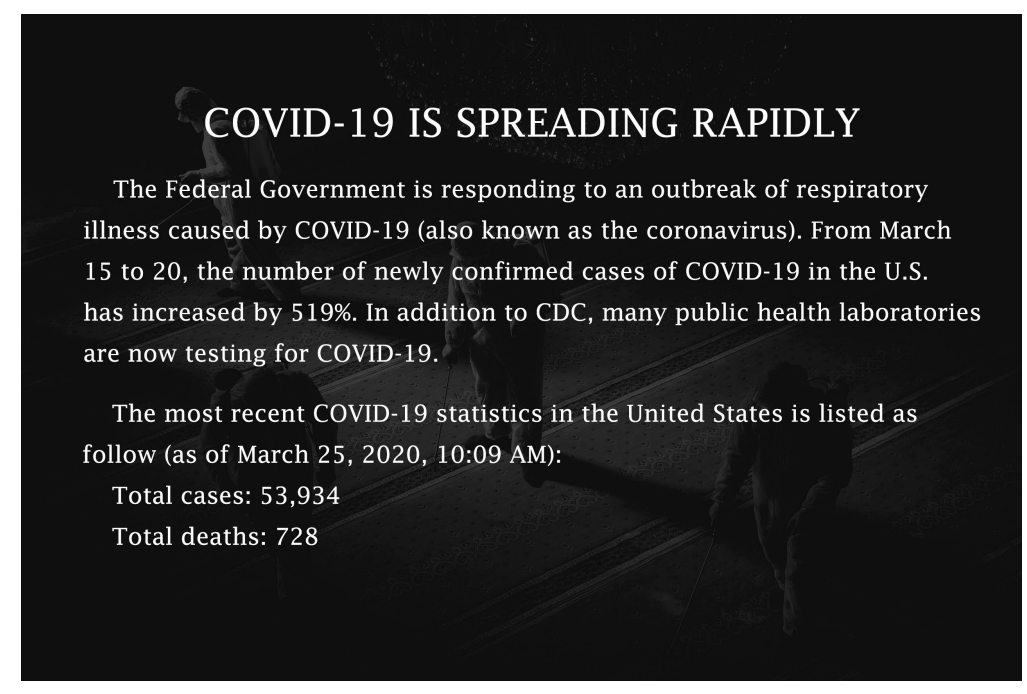

Overall, to that extent do you believe the federal government is deserving of blame for the current COVID-19 outbreak?

(0)Not at all to blame (100)Completely to blame

[Chinese Virus Condition] Please read the post below and answer following questions with this post in your mind. 


\section{CHINESE VIRUS IS SPREADING RAPIDLY}

The Federal Government is responding to an outbreak of respiratory illness caused by the Chinese Virus (also known as the coronavirus). From March 15 to 20, the number of newly confirmed cases of Chinese Virus in the U.S. increased by $519 \%$. In addition to CDC, many public health laboratories are now testing for Chinese Virus.

The most recent Chinese Virus statistics in the United States is listed as follow (as of March 25, 2020, 10:09 AM):

Total cases: 53,934

Total deaths: 728

Overall, to that extent do you believe the federal government is deserving of blame for the current Chinese Virus outbreak?

(0)Not at all to blame (100)Completely to blame

To confirm you've read and understood this post, please answer the following question. What is the name of the virus in the post that you have just read:

- Chinese Virus

- COVID-19

- Flu

[3-item list] Now we are going to show you three controversial statements related to the pandemic. After reading all three, just tell us HOW MANY of the that you AGREE with. (Remember: We don't want to know which ones, just how many)

- The pandemic will end in June.

- The virus will cause more than 2,000 deaths in the U.S.

- Every one should be wearing face masks in public areas.

Please also indicate whether you agree or disagree with the following statement: Chinese immigrants damage the public health in the U.S.

- Agree

- Disagree

[4-item list] Now we are going to show you three controversial statements related to the pandemic. After reading all three, just tell us HOW MANY of the that you AGREE with. (Remember: We don't want to know which ones, just how many) 
- The pandemic will end in June.

- The virus will cause more than 2,000 deaths in the U.S.

- Every one should be wearing face masks in public areas.

- Chinese immigrants damage the public health in the U.S.

[Demographics]

Are you...

- Male

- Female

Your age:

Do you consider yourself to be...

- White, not Hispanic or Latino

- Black, not Hispanic or Latino

- Hispanic or Latino

- Asian, not Hispanic or Latino

- Other

What was your total household income before taxes during the past 12 months?

- Less than $\$ 25,000$

- $\$ 25,000$ to $\$ 34,999$

- $\$ 35,000$ to $\$ 49,999$

- $\$ 50,000$ to $\$ 74,999$

- $\$ 75,000$ to $\$ 99,999$

- $\$ 100,000$ to $\$ 149,999$

- $\$ 150,000$ or more

How worried are you that you or someone in your family will be exposed to coronavirus?

- Very worried

- Somewhat worried

- Not too worried

- Not worried at all 
How often do you use or get information/news from Twitter/Facebook on an average day?

- Always

- Most of the time

- About half of the time

- Sometimes

- Never

In politics, as of today, do you consider yourself a Republican, a Democrat or an Independent?

- Republican

- Independent

- Democrat

[If Independent is selected] As of today, do you lean more to the Democratic Party or the Republican Party?

- Republican

- Democrat

- No opinion

How would you describe your political views as of today?

- Very conservative

- Conservative

- Moderate

- Liberal

- Very liberal

- No opinion

In which state do your current reside?

[Acknowledgment and Debrief Statement]

[End of Survey] 